\title{
Groundwater-surface water interaction between an esker aquifer and a drained fen
}

\author{
Pekka M. Rossi*, Pertti Ala-aho, Anna-Kaisa Ronkanen, Bjørn Kløve \\ University of Oulu, Department of Process and Environmental Engineering, Water Resources and Environmental Engineering Laboratory, P.O. Box 4300, 90014 University of \\ Oulu, Finland
}

\section{A R T I C L E I N F O}

\section{Article history:}

Received 27 October 2011

Received in revised form 27 January 2012

Accepted 7 February 2012

Available online 22 February 2012

This manuscript was handled by Philippe

Baveye, Editor-in-Chief, with the assistance

of Bernhard Wehrli, Associate Editor

\section{Keywords:}

Peatland

Preferential flow

Esker

Hillslope

Spring

Land-use

\begin{abstract}
S U M M A R Y
Groundwater discharge from an esker aquifer to a fen was studied to understand relevant hydrological processes for groundwater-surface water interaction in an esker-peatland hillslope. Piezometric levels of the peat layer and esker sand layer were continuously monitored and compared to climate data. Groundwater exfiltration points were spatially mapped and related to peat depth. The study showed a clear interaction between fen surface water and sand esker groundwater although the hydraulic conductivity of peat was low and the peat depth thick. In the artesian aquifer beneath the fen, the piezometric head showed a clear response to precipitation and evapotranspiration. Wetting of the peat is rapidly seen as pressure increase in the confined aquifer. This provides new information on hydraulics of wetlands found in aquifer discharge areas. Groundwater exfiltrated through thick peat layers in vertical preferential point discharges demonstrating how double porosity provides flow through the peat layer with low hydraulic conductivity in the peat matrix. The "pipe flow" channels were found in the deep peat area in the transition zones from deep peat to shallow peat. Diffuse seepage through the ditch bottom was found where ditches cut into the sand layer. Increased discharge through the ditch bed reduced the flow resistance at the aquifer boundary which can lower the groundwater level in the esker. The results show new processes in the groundwater discharge zone that are useful for groundwater modelling and policy development for future groundwater protection.
\end{abstract}

(c) 2012 Elsevier B.V. All rights reserved.

\section{Introduction}

Eskers are glacial sand and gravel deposits that were formed during the last deglaciation period. During ice melt, subglacial rivers left behind sand and gravel at thicknesses up to $100 \mathrm{~m}$. Today, these features are one of the main aquifer types on the Fennoscandian shield (Kløve et al., 2011). Besides their function as a water supply, eskers are used for recreation and forestry. Eskers typically have a unique landscape with clear groundwater-fed lakes. The main threats to esker groundwater level and ecosystems are extraction of gravel and increasing use of groundwater as a drinking water supply (Britschgi et al., 2009; Rintala, 2006). Additionally, peatland drainage in an aquifer discharge zone is a threat that is not very well understood. Since 1984, many eskers have been protected in the Finnish Esker Protection Programme or by the European Union (EU) Habitat Directive and its Natura 2000 network.

Eskers are typically unconfined aquifers which discharge groundwater to nearby features such as springs, lakes, rivers and fens. Around most eskers in the boreal zone, peatlands cover large

\footnotetext{
* Corresponding author. Tel.: +358 8553 4395; fax: +358 85534507.

E-mail addresses: pekka.rossi@oulu.fi (P.M. Rossi), pertti.ala-aho@oulu.fi (P. Ala-aho), anna-kaisa.ronkanen@oulu.fi (A.-K. Ronkanen), bjorn.klove@oulu.fi (B. Kløve).
}

parts of the discharge area and locally confine the groundwater. In many regions of the world, fens have been drained for agriculture, forestry or peat harvesting. Since the 1950s most of the pristine peatland areas in Finland have been ditched to increase forest growth (Aapala, 2001). Despite the potential impact on groundwater, the impacts of these forestland ditches on groundwater levels and discharge has not been studied before. Rather, the main focus has been on protecting the recharge area. The impact of land-use in the discharge zone has not been seen to directly affect the esker ecosystem. However, increasing discharge from the esker after ditching could lower the groundwater level which can influence groundwater-dependent lakes and wetlands in the recharge area (Kløve et al., 2011). A key to understanding if fen drainage affects groundwater is the hydraulic connection between a discharge wetland area and the upslope esker aquifer.

Hydraulic properties of peat have been studied for the past decades in various in situ and laboratory studies (e.g. Price, 1992; Schlotzhauer and Price, 1999; Beckwith and Baird, 2001), but groundwater exfiltration into peatlands is not well understood. Hydraulic conductivity of peat decreases with depth and changes drastically at the interface between acrotelm and catotelm. In studies by Päivänen (1973), Holden and Burt (2002) and Ronkanen and Kløve (2005) hydraulic conductivity of peat matrix varied from $0.01 \mathrm{~m} \mathrm{~s}^{-1}$ to $10^{-10} \mathrm{~m} \mathrm{~s}^{-1}$. Peat can also have double porosity, where 


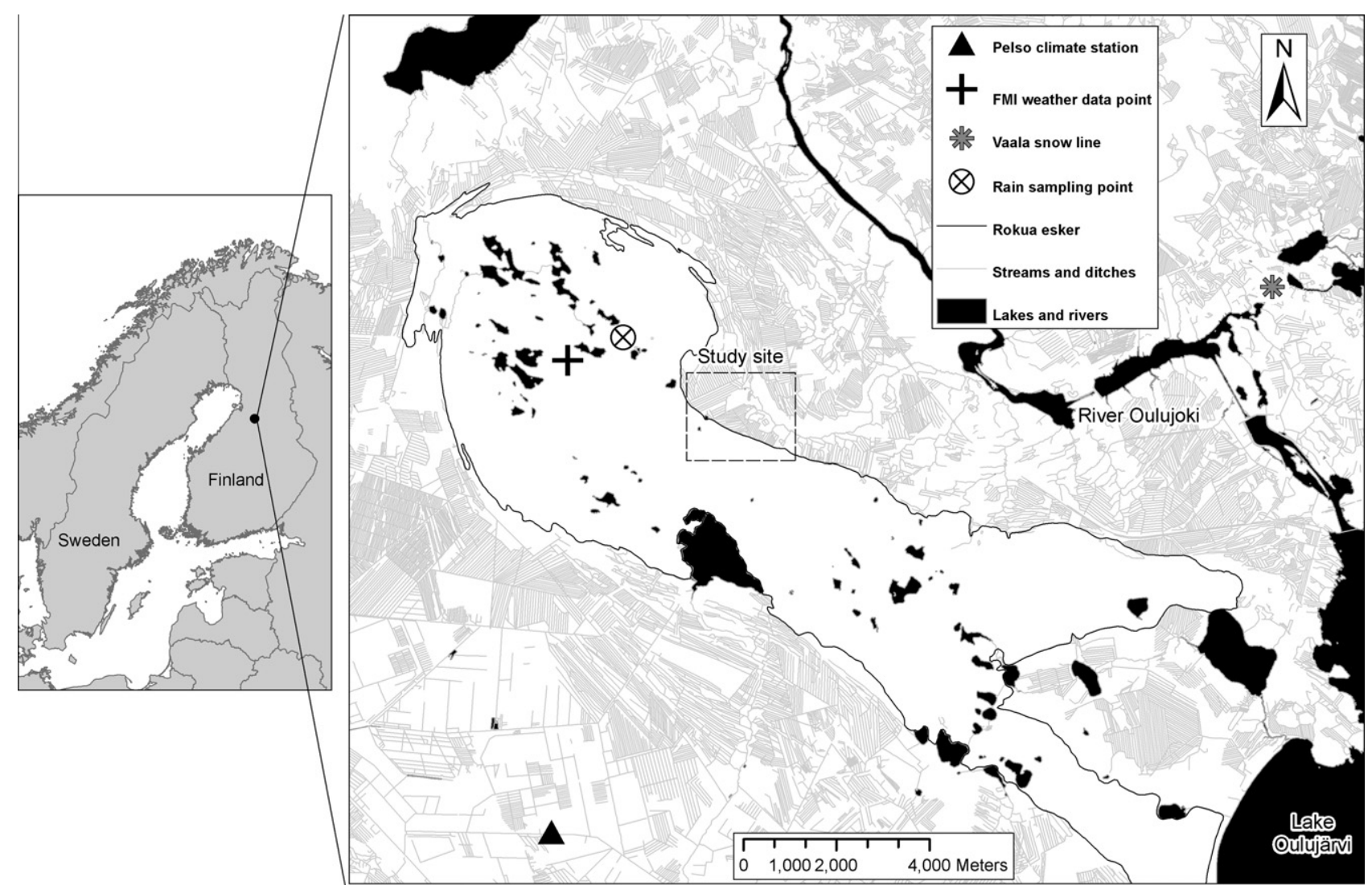


rain sampling point.

water flows in the peat matrix and in concentrated passageways as pipeflow (Gilman and Newson 1980; Ours et al., 1997). Horizontal pipeflow has been noted in studies of hilly blanket mires where storm water moves downstream rapidly by surface runoff and horizontal pipeflow (Holden and Burt, 2002; Holden, 2005). Studies by Lowry et al. (2009) suggest that the double porosity could be the cause for spring formation in peatlands: If the piezometric head is higher in the mineral soil below peat, the confined groundwater could eventually find its way through the peat in the form of vertical pipeflow. Confined groundwater seepage through peat has also been conceptually presented by Langhoff et al. (2006). In both cases groundwater discharged in areas where the peat depth rapidly decreased from 3-4 $\mathrm{m}$ to less than a metre.

As the hydraulic conductivity of peat can be very low, it can in theory work as an aquitard. For example in a Danish fen ecosystem, Johansen et al. (2011) showed that peat functions as a partially impermeable layer. They concluded that the effect of groundwater intake from the confined sand aquifer under the fen peat does not affect the peat layer groundwater level but lowers the discharge of natural springs and confined piezometric heads in the area. For assessment of ecosystem impacts after groundwater withdrawal the interaction between fens and groundwater must be understood (Dahl et al., 2007). The recent EU groundwater directive asks for a better understanding of how terrestrial ecosystems are connected to groundwater (EC, 2008). The groundwater body status assessment also depends on the status of ecosystems relying on groundwater.

The main objective of this paper is to understand how groundwater from an esker discharges and interacts with a drained fen. In many cases drains are a boundary to groundwater systems and this interaction is therefore of general importance and required for groundwater modelling. We studied how wetting of peatland in the esker discharge zone influences the hydraulic pressure head in the sand aquifer. We also demonstrate that the contact between groundwater and peat depends on whether preferential flow (double porosity) channels are formed in the peat. This is important for groundwater protection as low hydraulic conductivity in the peat matrix does not prevent contact between peatland ditches and the underlying aquifer. We also show how discharge patterns are spatially distributed in a complex way and how ditching influence this distribution.

\section{Study site and methods}

\subsection{The Rokua esker}

The Rokua esker area is situated in Northern Finland, $100 \mathrm{~km}$ inland from the coast. It has a recharge area of $90 \mathrm{~km}^{2}$. It is one of the largest aquifers in Finland and is protected by the EU Natura 2000 directive and other national conservation programs. Its highest elevation is $100 \mathrm{~m}$ above the surrounding peatlands (Fig. 1). The esker consists mainly of sand with layer thicknesses varying from $30 \mathrm{~m}$ to more than $100 \mathrm{~m}$ above the bedrock. Rokua has a rolling terrain because of kettle formations formed by melting ice blocks and dunes formed after ice retreat following the last ice age. The surrounding peatlands started to form 8000 years ago between littoral deposits of different phases of the Baltic Sea (Pajunen, 1995). Peatlands are mostly aapa mires with peat layers up to several metres thick. The majority of the peatlands were ditched for forestry during the time period from the 1950s to 1980s (Fig. 1).

In order to study groundwater discharge into the ditched peatland, a study site area located in the upper catchment area of the Siirasoja stream was chosen (Fig. 1). The Siirasoja stream had one 


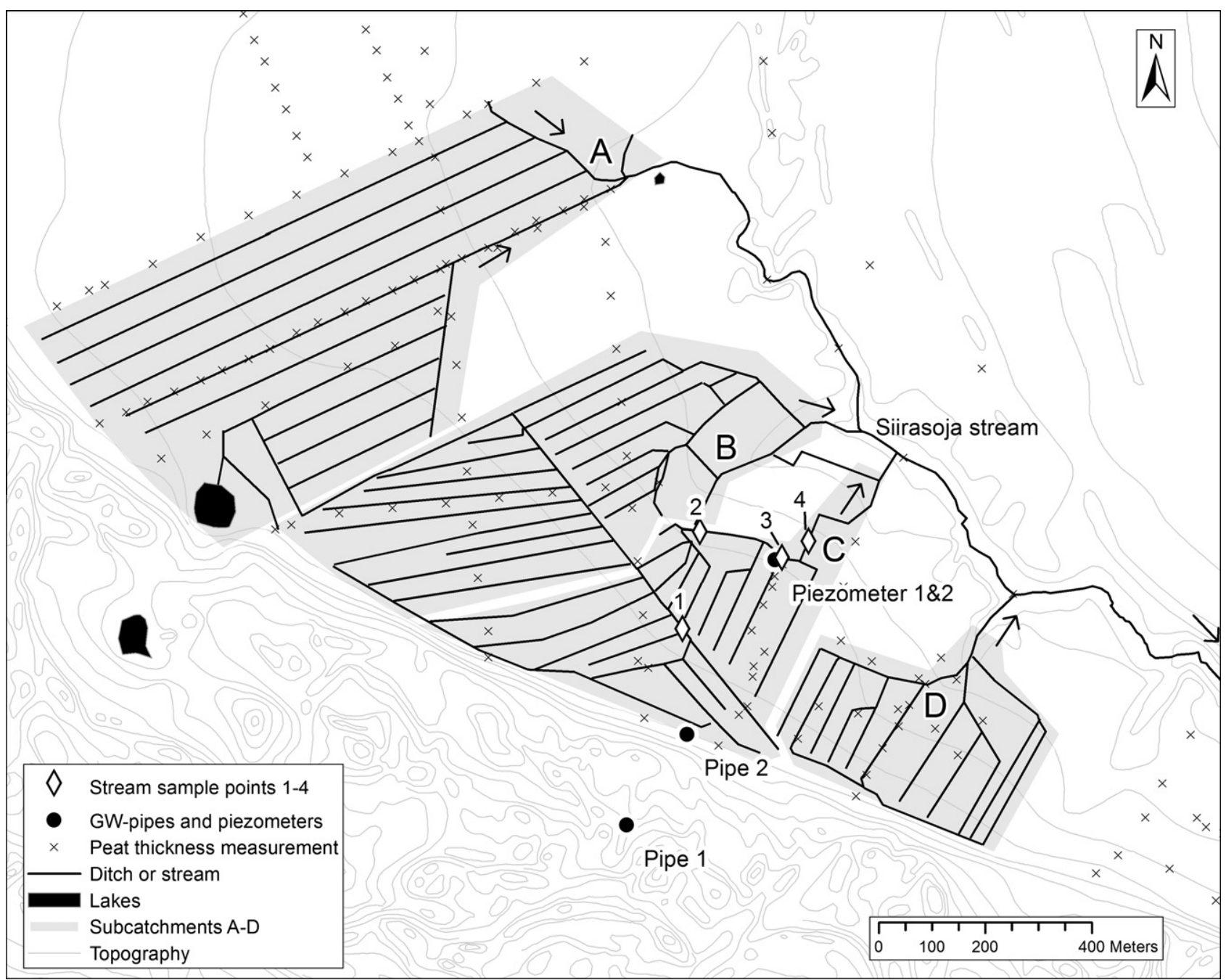

Fig. 2. Siirasoja stream study site sub-catchments A-D showing the groundwater pipes, piezometers, stream sample points and peat thickness measurement points.

of the highest runoff of the streams surrounding Rokua during dry season measurements conducted in Rokua in July 2009 and July 2010. The study area $\left(1.5 \mathrm{~km}^{2}\right)$ was divided into sub-catchments A-D (Fig. 2). These ditched peatland areas had a mixture of forest types from dense new forest to thin older forest and clear cuttings. The esker formation rises steeply (30\%) on the southern side of the peatland.

\subsection{Hydrogeological measurements}

All ditches in the study area were examined in situ during the low-flow season of July 2009 and classified by their discharge volumes according to measurements recorded with a current meter (Mini Air 20). In addition, in May 2010 two v-notch weirs were installed at sub-catchment $C$ for continuous discharge measurements (sample points 2 and 4, Fig. 2). Water level loggers (Solinst Levelogger Gold) were installed at the weirs for hourly measurements.

Groundwater exfiltration points in ditches were identified and classified as either point or diffuse exfiltration types. Spring-like groundwater point discharges were first visually observed and then confirmed with water temperature measurements from the ditch water before and after the observed point. Because the temperature of the groundwater was approximately $10^{\circ} \mathrm{C}$ colder than surface water during the in situ study period, the temperature difference could be used as a tracer (see e.g. Anibas et al., 2011). If no point discharge was observed and the discharge of a ditch increased and water temperature was low, these ditches were classified as having groundwater seepage discharge.

The hydrogeological structure of the area was studied using a variety of methods. Esker formation thickness was studied with drilling to bedrock at groundwater pipe 1, represented in Fig. 2. At the drilling point, the esker consisted of 83.4-m-thick layer of homogeneous sand with a mean $d_{50}$ grain size of $1.961 \mathrm{~mm}$ and a standard deviation of $0.065 \mathrm{~mm}$ (10 samples). Peat layer thickness in the area was studied by Häikiö (2008). These measurements were supplemented with additional manual peat drillings and ground-penetrating radar measurements (Malå $100 \mathrm{MHz}$ GPR-system) in 2009 and 2010 (Fig. 2). Spatial distribution of peat thickness was interpolated for the area using the natural neighbour method (140 measurement points in the study site). Groundwater level in sand and peat layers was recorded hourly from piezometers and groundwater pipes in the area (Figs. 2 and 3) using water level loggers (Solinst Levelogger Gold).

The hydraulic conductivity of peat was measured using a directpush piezometer with a falling head (Hvorselv, 1951). Measurements were taken at four locations of the study area from different depths $(20-200 \mathrm{~cm})$. The hydraulic conductivity varied in these measurements from $10^{-5} \mathrm{~m} \mathrm{~s}^{-1}$ at the depth of $20 \mathrm{~cm}$ to $10^{-9}$ $\mathrm{m} \mathrm{s}^{-1}$ at the depth of $200 \mathrm{~cm}$. Hydraulic conductivity values for sand 


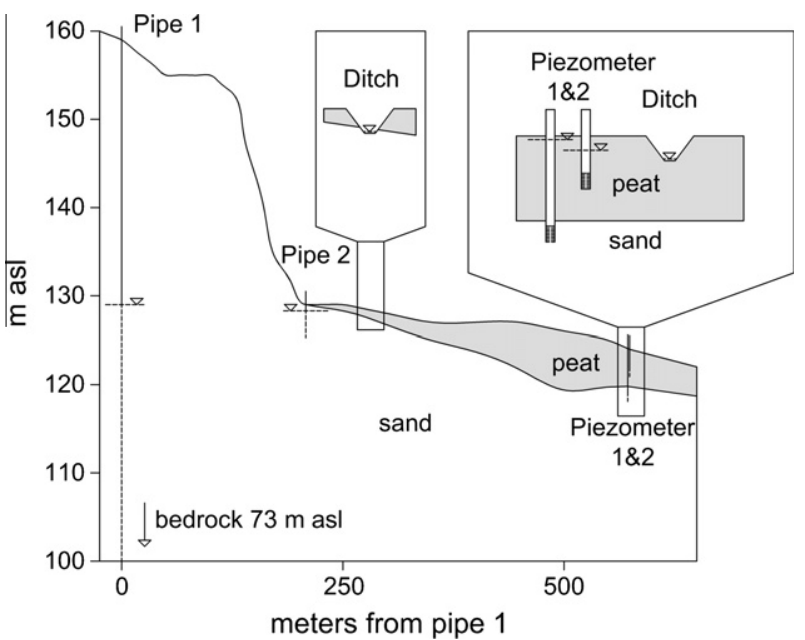

Fig. 3. Cross-section of the study site from groundwater pipe 1 to piezometers 1 and 2. Horizontal axis has 10:1 exaggeration.

of $2 \mathrm{~mm} d_{50}$ grain size are usually from $10^{-3} \mathrm{~m} \mathrm{~s}^{-1}$ to $10^{-6} \mathrm{~m} \mathrm{~s}^{-1}$ (Davis, 1969). Hydraulic conductivities were used in Geoslope and Topodrive programs to outline groundwater flow routes.

Precipitation records from 1 July 2009 to 1 July 2010 were obtained from the Finnish Meteorological Institute (FMI) Pelso Climate Station located $10 \mathrm{~km}$ from the study site (Fig. 1). Moreover, local precipitation was also ensured at the Siirasoja stream using a tipping bucket at a 1-h measurement interval during the time period from 22 May 2010 to 1 July 2010. The snow water equivalent was measured by the Finnish Environment Institute (SYKE, 2011) at the snow line in Vaala, $11 \mathrm{~km}$ from the study site (Fig. 1). Evapotranspiration for the study site was estimated using the FAO Penman-Monteith equation (Allen et al., 1998).

Data for meteorological variables was provided by FMI. Daily temperature was measured at the Pelso Climate Station. Data records for relative humidity, wind speed and global radiation were obtained from a $10 \times 10 \mathrm{~km}$ grid interpolation (FMI) with the node shown in Fig. 1. Applying the FAO Penman-Monteith equation during winter can lead to erroneous results because assumptions for reference evapotranspiration calculations are contradicted for snow cover period (Allen et al., 1998). This was taken to account by setting the evapotranspiration to zero for days when the maximum temperature was below $0{ }^{\circ} \mathrm{C}$.

In addition to field observations and discharge measurement, natural tracers ( $\mathrm{SiO}_{2}, \mathrm{Ca}, \mathrm{pH}$ and electrical conductivity) were measured from the study site to clarify groundwater flow paths and exfiltration to the ditches on the hillslope scale. Water samples were taken in June 2010 from stream sample points 1-4, groundwater pipes, piezometers (Fig. 2) and from rainwater (Fig. 1). In one stream section, also a mixing analysis was conducted using $\mathrm{SiO}_{2}$ as a natural tracer. $\mathrm{SiO}_{2}$ is typical in groundwater and surface water mixing studies (e.g. Hooper and Shoemaker, 1986; Wels et al., 1991; Iorgulescu et al., 2005) as precipitation usually has a very low concentration of $\mathrm{SiO}_{2}$. Samples were analysed by Finnish Environmental Institute (SYKE) laboratory, accredited for water sample analyses by the Finnish Accreditation Service.

The mixing analysis is based on conservation of mass and water balance and to the assumption that the used tracer $\mathrm{SiO}_{2}$ is chemically conservative. The mixing ratio was calculated between the stream sample points 2 and 4, where discharge was measured with

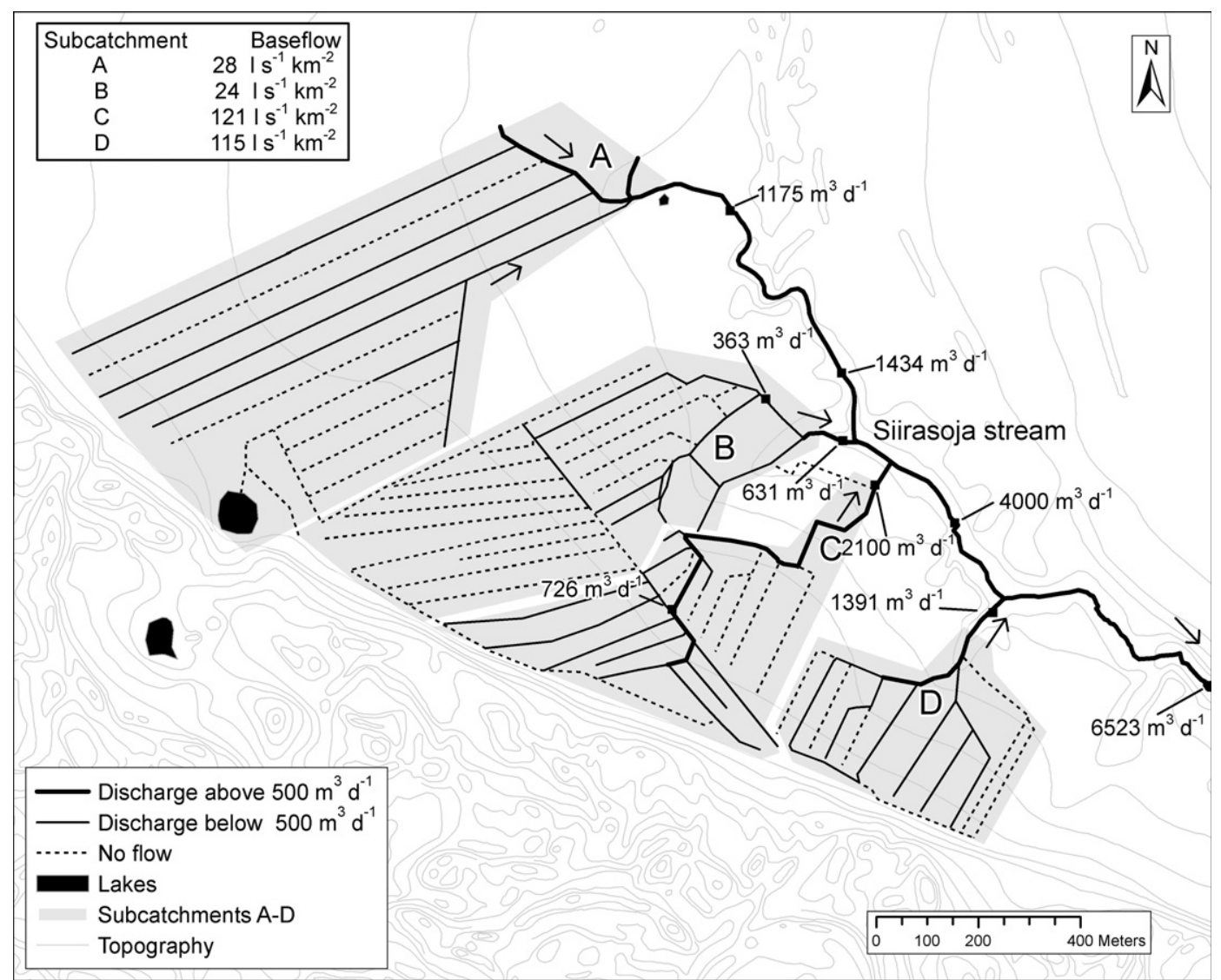

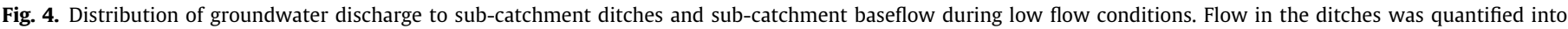
three categories: more than $500 \mathrm{~m}^{3} \mathrm{~d}^{-1}$, less than $500 \mathrm{~m}^{3} \mathrm{~d}^{-1}$ or no flow. The largest discharge was measured from sub-catchment $\mathrm{C}$. 


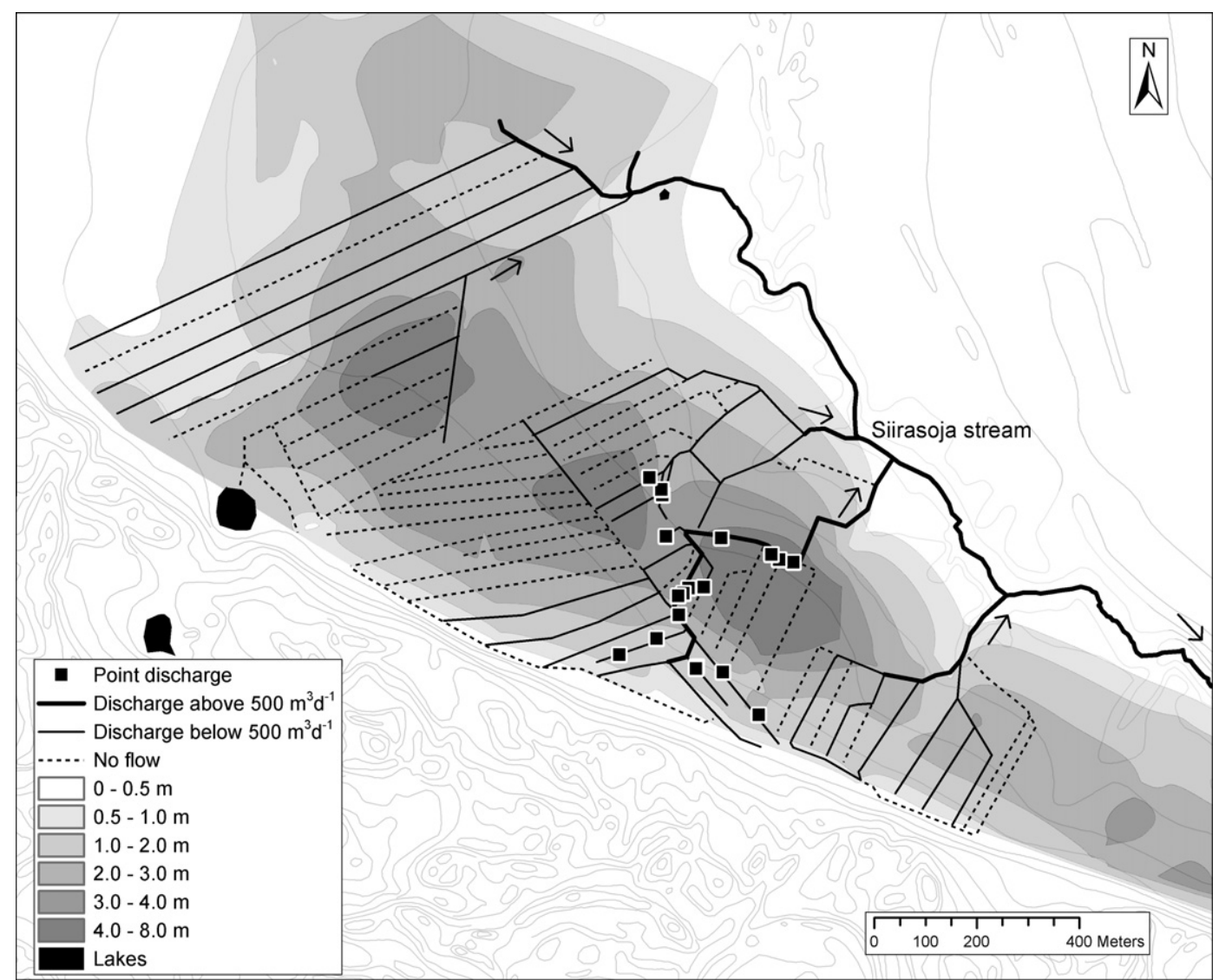

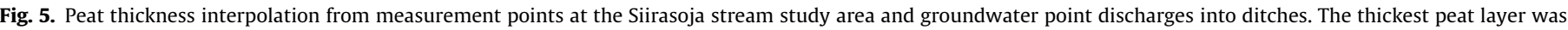
measured at sub-catchment C. Point discharges were mostly observed in sub-catchment C. No point discharges were observed in sub-catchment D.

v-notch weirs. Mixing analysis was used to define the ratios of water exfiltrating from the peat aquitard and from the sand aquifer to the stream section between the v-notch weirs. The mixing analysis was calculated using four end-points in eq. (1):

1. Upstream v-notch weir (stream sample point 2).

2. Peat aquitard (tracer sample from piezometer 1 ).

3. Sand aquifer (tracer sample from piezometer 2 ).

4. Downstream v-notch weir (stream sample point 4).

$Q_{4} C_{4}=Q_{1} C_{1}+Q_{2} C_{2}+Q_{3} C_{3}$

where $Q_{1-4}$ is the discharge of component, $\mathrm{m}^{3} \mathrm{~d}^{-1}, C_{1-4}$ is the concentration of end-point $1-4$ sample, $\mathrm{mg} \mathrm{l}^{-1}$.

From eq. (1) discharge for the peat aquitard and the sand aquifer was calculated:

$Q_{2}=\frac{Q_{4}\left(C_{3}-C_{4}\right)+Q_{1}\left(C_{1}-C_{3}\right)}{C_{3}-C_{2}}$

$Q_{3}=\frac{Q_{4}\left(C_{2}-C_{4}\right)+Q_{1}\left(C_{1}-C_{3}\right)}{C_{2}-C_{3}}$

Rain water was not taken into account in these calculations as all samples were taken during a dry period defined as no rain in 3 days.

\section{Results}

The groundwater from the esker discharged into the fen in a complex spatial pattern. A high variation in the amount of baseflow, 24-121 $1 \mathrm{~s}^{-1} \mathrm{~km}^{-2}$, was observed between the four fen sub-catch- ments A-D (Fig. 4). These runoff values are higher than typical baseflow values of $1.5-31 \mathrm{~s} \mathrm{~s}^{-1} \mathrm{~km}^{-2}$ in Northern Finland (Mustonen, 1986), indicating strong groundwater exfiltration. A high variation was also seen within each sub-catchments as some ditches had discharge amounts above $500 \mathrm{~m}^{3} \mathrm{~d}^{-1}$, whereas adjacent ditches had no flow.

The groundwater exfiltration occurred as point discharge and even diffuse seepage along the ditch bed. Point discharges were mainly found in catchment $C$ with the highest baseflow and deepest peat layers of a maximum thickness of $8 \mathrm{~m}$ (Fig. 5). These point discharges show a direct connection between esker groundwater and surface runoff in ditches despite deep peat layers of low hydraulic conductivity. In sub-catchment $\mathrm{D}$, no point discharges were observed, but the baseflow was almost as high as in subcatchment $\mathrm{C}$. The peat layer in the sub-catchment $\mathrm{D}$ was shallow (0.5-2 $\mathrm{m})$ and some ditches had been cut through the peat into the mineral soil providing a direct connection between the aquifer and the ditches.

The double porosity point discharge through the peat was induced by a high pressure level in the aquifer below the peat layer. The pressure head in the sand layer beneath the peat (measured from piezometer 1) was always higher than the groundwater level in the peat layer (measured from piezometer 2) during the measurement period (Fig. 6). On the edge of the esker hillside (groundwater pipe 1) and at the esker (groundwater pipe 2), the aquifer was unconfined. During the measurement period, the groundwater level and pressure level in all of the sand layer measurement points varied between $11 \mathrm{~cm}$ (piezometer 2) and $14 \mathrm{~cm}$ (groundwater pipe 2).

The groundwater pressure directly below the peat deposit and further uphill in the recharge area showed a clear response to 

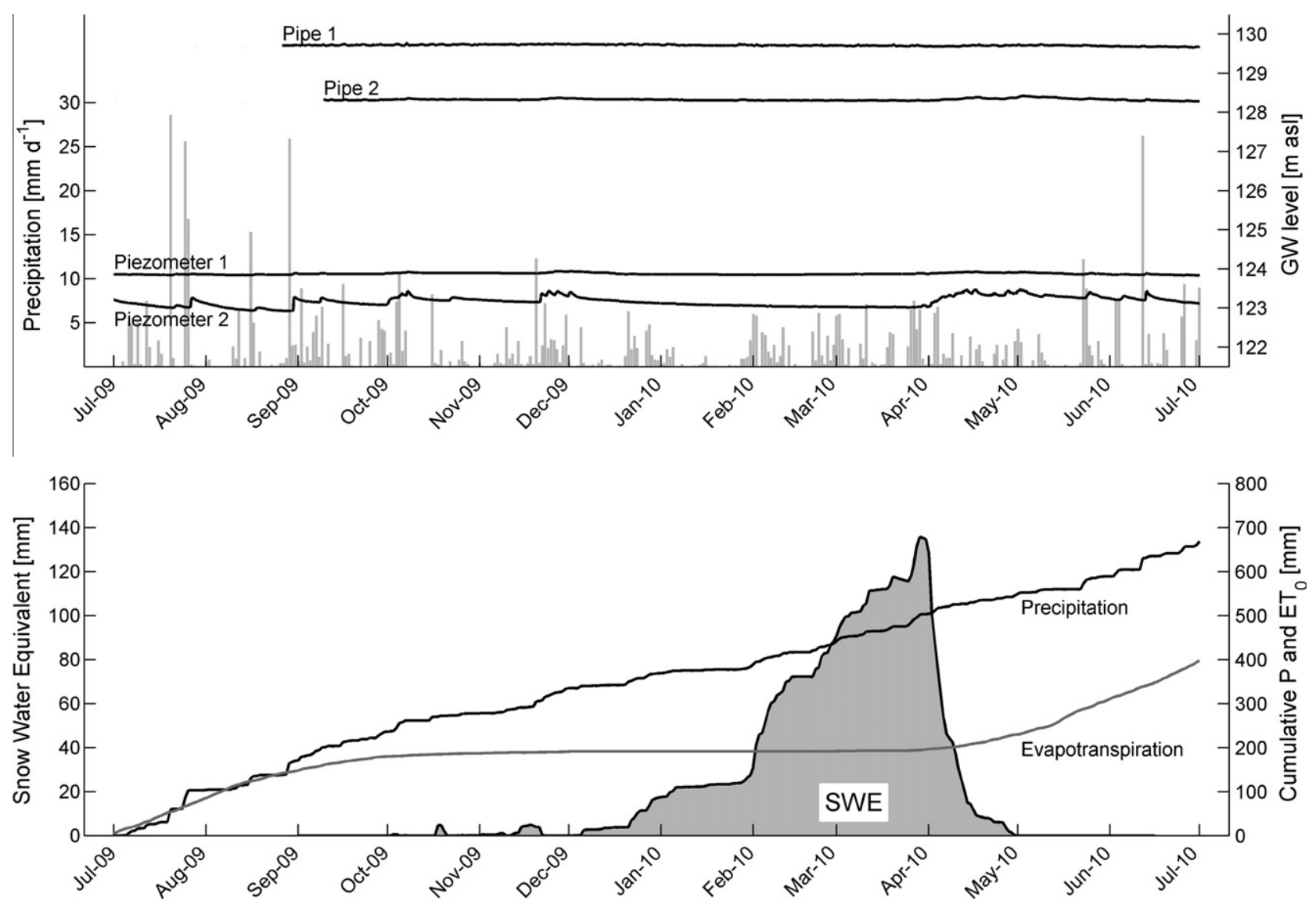

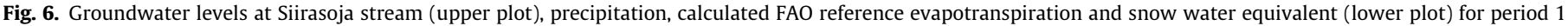
July 2009-1 July 2010.

rainfall. Both peat layer water level (piezometer 2) and sand layer pressure level (piezometer 1 ) peaked after rain events within 1-2 $\mathrm{h}$ delay (Fig. 7). The increase in sand layer piezometric pressure level was similar to the depth of areal precipitation (Table 1). Considering the three longest rainless periods (Table 1 ), the average rate of piezometric level declined in the sand layer at the rate of 2.9 $\mathrm{mm} \mathrm{d}^{-1}$. As piezometric data was compared to the climate data, it was noted that the rate of piezometric level decline during the dry periods was of same magnitude as the average daily reference evapotranspiration calculated using the FAO Penman-Monteith equation (3.1 $\left.\mathrm{mm} \mathrm{d}^{-1}\right)$.

The water in study site showed a high variability in chemical composition (Fig. 8). For example the silica concentration in ditches varied between 11 and $14 \mathrm{mg} \mathrm{l}^{-1}$ and in the sand layer between 7 and $16 \mathrm{mg} \mathrm{l}^{-1}$. In peat, silica concentration $\left(1.2 \mathrm{mg} \mathrm{l}^{-1}\right)$ was closer to rain water concentration $\left(<0.1 \mathrm{mg} \mathrm{l}^{-1}\right)$. All measured concentrations and parameters were highest in the sand layer beneath the peat (piezometer 1 ). The flow rate in the ditch between sample points 2 and 4 increased $1400 \mathrm{~m}^{3} \mathrm{~d}^{-1}$. Using esker groundwater and peat water as end-points, the mixing analysis with $\mathrm{SiO}_{2}$ shows a discharge increase from the sand aquifer of $1300 \mathrm{~m}^{3} \mathrm{~d}^{-1}$ and $100 \mathrm{~m}^{3} \mathrm{~d}^{-1}$ from the peat layer.

\section{Discussion}

\subsection{Groundwater exfiltration in drained fens}

In order to assess groundwater flow paths in eskers, the discharge patterns must be properly understood to set correct boundary conditions. The groundwater discharge patterns can be observed by dividing the studied area into sub-catchments of ditches and measuring the discharge rates during low flow. For a detailed analysis, each ditch must be observed and areas of point discharge and diffuse seepage must be determined.

As suggested by Lowry et al. (2009) vertical pipeflows (or preferential flow) can form in peat and these can cause spring-like point discharge formations, as happened in several points at the Rokua Siirasoja study site ditches. These point discharges seemed to occur where the peat is fairly deep, indicating that peat depth or matrix hydraulic conductivity does not prevent exfiltration. The mixing analysis suggested that point discharges can increase the discharge on a $200 \mathrm{~m}$ ditch section by as much as $1300 \mathrm{~m}^{3} \mathrm{~d}^{-1}$, whereas surface runoff from the peat layer was $100 \mathrm{~m}^{3} \mathrm{~d}^{-1}$.

The detailed survey of sand and peat topography showed that the point discharge occurred on transition areas where peat layer thickness changed from thick to thin (Fig. 9). It is not known if point discharges emerged in the area after drainage, or if they have already existed as natural springs before drainage. Groundwater diffuse seepage into ditches occurred in places where the peat layer was penetrated and the ditch had a direct connection to the sand layer. Both of these exfiltration types were caused by a higher water pressure level in the sand layer compared to the ditch water level (Fig. 9). Generally, the drainage network facilitated exfiltration into ditches by providing a network for conveying water from the discharge area. Ditches also increased piezometric pressure difference between the free water surface (ditch water level) and the sand aquifer.

\subsection{Sand aquifer response to rain events and to evapotranspiration}

The wetting of the fen during rain events seems to have a direct impact on the groundwater pressure head in the sand aquifer. As 

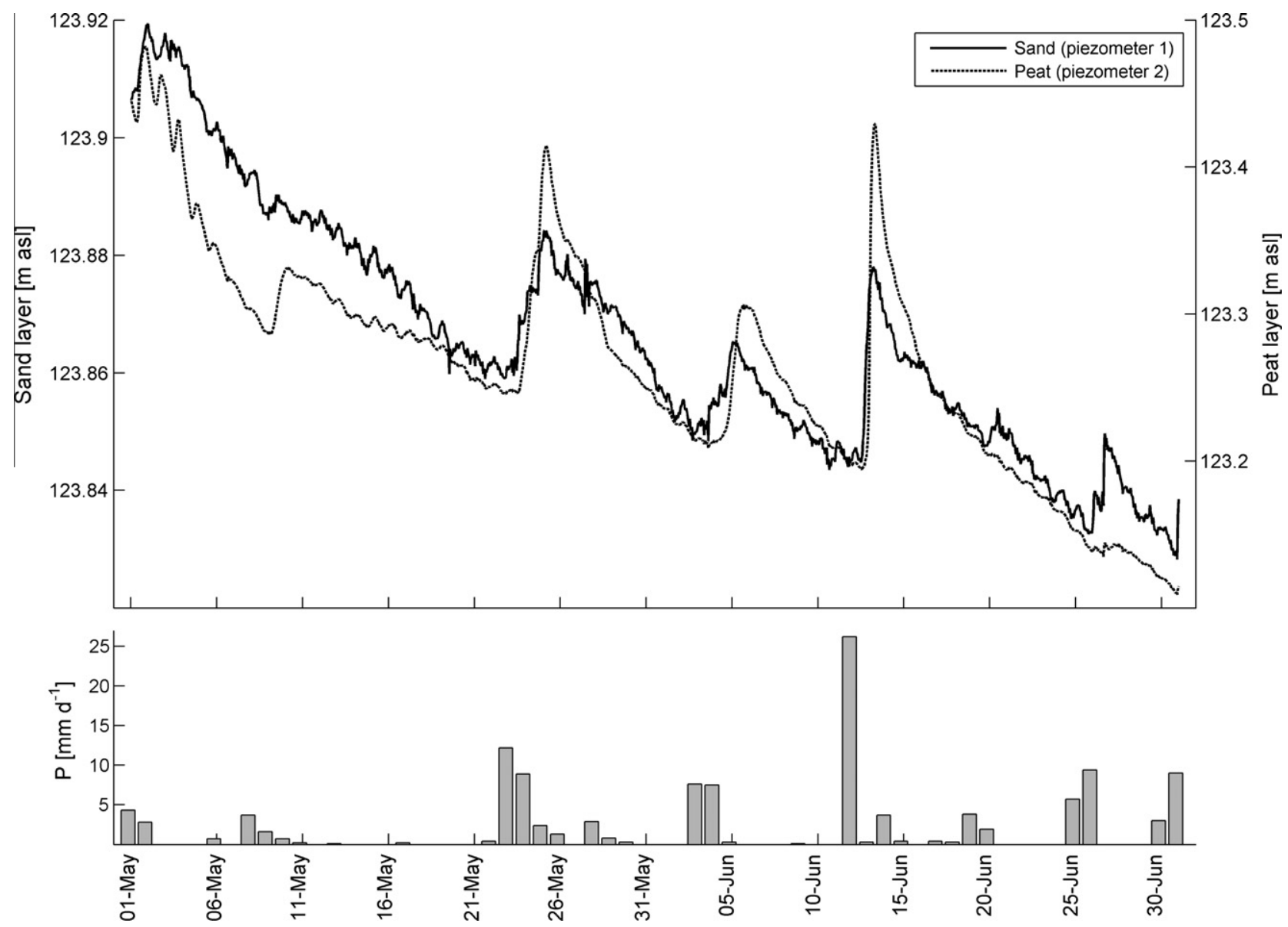

Fig. 7. Groundwater levels in sand (piezometer 1) and peat (piezometer 2) in comparison with daily precipitation for the period 1 May $2010-1$ July 2010.

the peat is an aquitard above the sand, rain events should not directly affect the sand layer pressure level. However, the results showed a quick pressure level response to rain. This pressure level change could also be caused by recharge at the unconfined part of the esker aquifer, but the response would be less immediate due to considerable residence time in the thick unsaturated zone. Thus, the pressure level rise in the sand layer below the peat was most likely caused by the mass increase of the peat layer by rain water. Data analysis showed that the piezometric level increase was close to the precipitation depth measured at the Pelso Climate Station (Table 1).

The observation that precipitation affects groundwater levels in both peat layer and sand aquifer can be explained by peat soil water retention characteristics and the depth of groundwater level in the peat layer. During dry conditions in the fen, the rainwater is presumably absorbed into the unsaturated zone of the peat layer, because no increase in peat groundwater level is observed. This is seen after the rain event of 25 and 26 of June (Fig. 7). This rain event only increased the sand layer pressure level, probably induced by increase of mass in the peat layer due to retained water in the unsaturated peat soil.

On the other hand a quick response in the peat groundwater level was observed during the rain events of 8 and 9 of May. On this occasion only a small amount of precipitation changed the peat groundwater level considerably. This might be caused by peat soil moisture content being closer to full saturation after the spring time snowmelt. The response of the peat layer groundwater level dependence on the moisture status of the peat soil preceding the precipitation event indicates threshold behaviour. The sand aquifer underlying the peat responded consistently to all precipitation
Table 1

Changes in sand layer piezometric head level compared to precipitation $(P)$ and reference evapotranspiration $\left(\mathrm{ET}_{0}\right)$.

\begin{tabular}{lll}
\hline Time of recorded level rise & $\begin{array}{l}\text { Piezometric level } \\
\text { rise in sand }(\mathrm{mm})\end{array}$ & $\begin{array}{l}P \\
(\mathrm{~mm})\end{array}$ \\
\hline 22 May 2010 20:00-25 May 2010 04:00 & 25.1 & 25.2 \\
3 June 2010 14:00-5 June 2010 02:00 & 15.6 & 15.4 \\
12 June 2010 09:00-13 June 2010 05:00 & 32.9 & 30.2 \\
25 June 2010 18:00-26 June 2010 17:00 & 17.1 & 15.1 \\
Time of recorded level decline & Piezometric level & $\mathrm{ET}_{0}$ \\
& decline in sand $(\mathrm{mm})$ & $(\mathrm{mm})$ \\
\hline 11 May 2011 0:00-20 May 2011 0:00 & 23.0 & 29.8 \\
5 June 2011 0:00-11 June 2011 0:00 & 19.5 & 15.9 \\
21 June 20110:00-24 June 2011 0:00 & 8.8 & 10.3 \\
\hline
\end{tabular}

events with level rise closely matching the depth of precipitation (Table 1).

During the dry seasons of May and June 2010, the piezometric water level in the sand and water level in the peat decreased. The average rate of piezometric decline in the sand layer was in agreement with the average reference evapotranspiration rate $\left(\mathrm{ET}_{0}\right)$ calculated using the FAO Penman-Monteith equation. This observation can be considered as a reverse phenomenon compared to the precipitation events discussed above, where the depth of precipitation was consistent with the pressure level rise in the sand layer piezometer. The mass of water evaporating from the peat layer and vegetation reduces the pressure in the sand layer.

If assumed that water lost from the peat layer to the drainage ditches during dry seasons is minor compared to evapotranspiration 

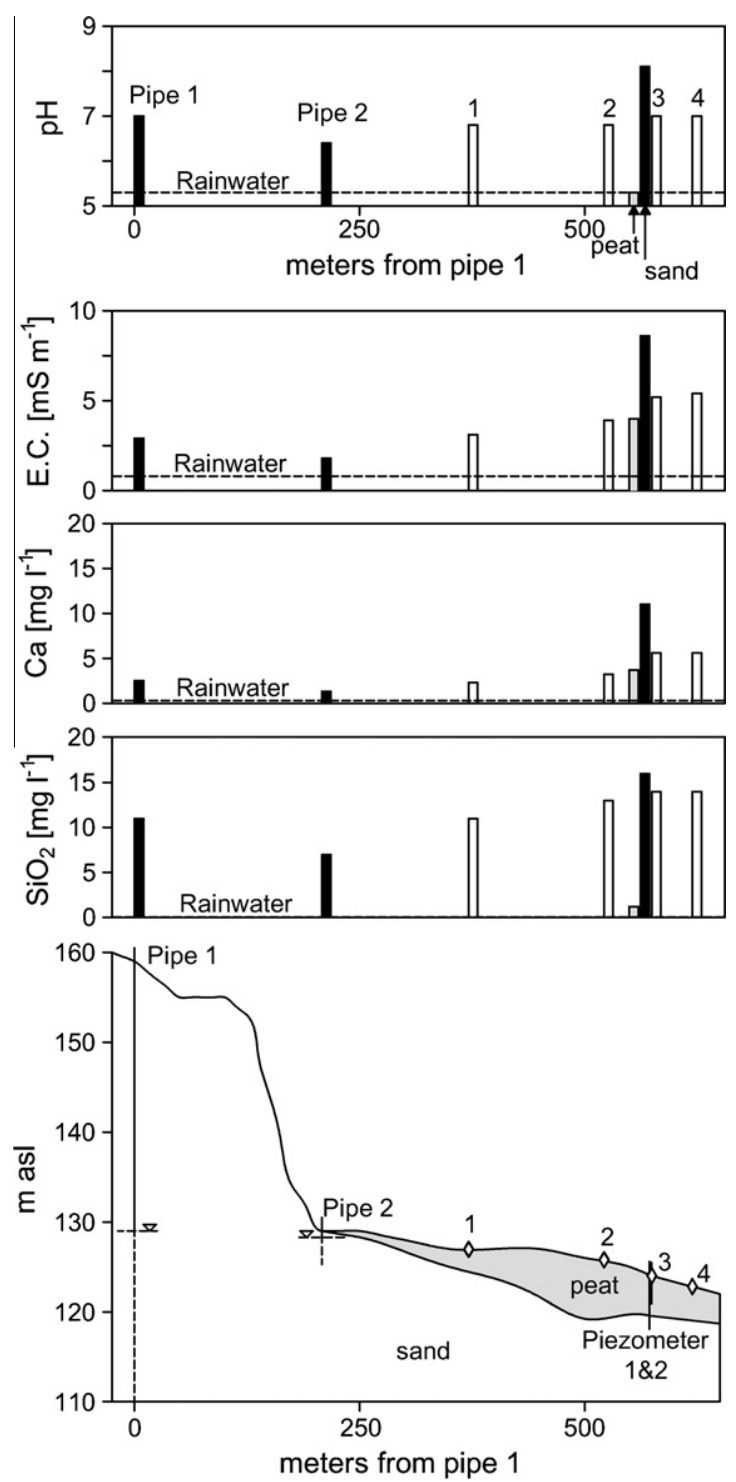

Fig. 8. pH electrical conductivity (E.C.), calcium and silicon dioxide measurements from groundwater pipes, piezometers and stream water samples in June 2010. Black columns represent samples from the sand layer, the grey column represent samples from peat and white columns from the ditch. Dashed line represents the sample from rain water.

in the peat layer water balance, the rate of pressure head decline in the sand layer can be expected to be equal to the rate of evapotranspiration as observed. It is still possible that calculated $\mathrm{ET}_{0}$ overestimates the amount of daily evapotranspiration. Parameterization in the reference $\mathrm{ET}_{0}$ is not modified to match study site vegetation and the method calculates the potential, not the actual evapotranspiration. Part of the piezometric head decline in the sand layer can also be caused by loss of water from the peat layer to the drainage ditches as some drainage flow from the peat layer is also seen in the results of the mixing analysis.

Comparison of sand layer piezometric level variation and climate data gives an insight to water balance of the peat layer. Close equivalence of precipitation and evapotranspiration to the sand layer piezometric head variation suggests that the pressure head could be considered as a "scale" to measure changes in the weight of the peat layer. This creates an interesting possibility to use the changes in the piezometric pressure head of the sand layer to estimate precipitation-evapotranspiration phenomena of the peat layer. To make such an estimation method more rigorous, the water

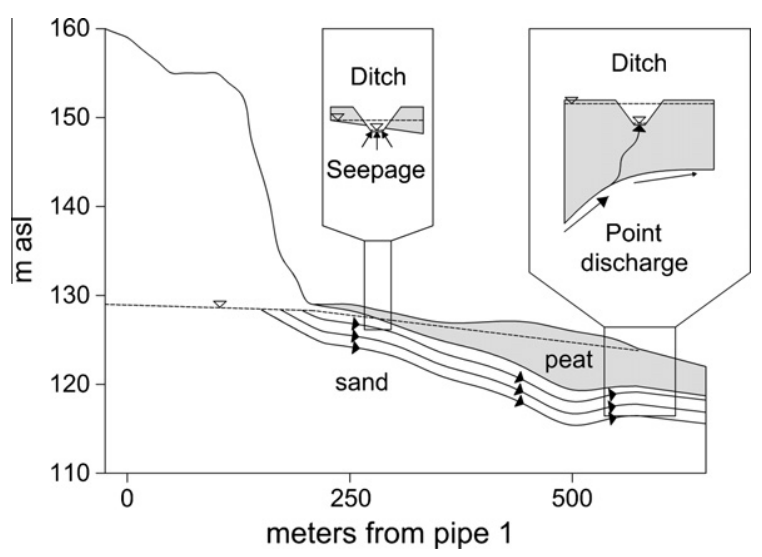

Fig. 9. Conceptualization of groundwater flow below peat layer and groundwater flow mechanisms to ditches at the Siirasoja stream study site.

retention capacity of the peat and the amount of water flow from the peat layer to ditches should be more accurately determined.

\section{Conclusions}

Groundwater from esker aquifers discharges in a complex pattern into the surrounding fens. Under the fens the groundwater is confined with higher than atmospheric pressure. The groundwater exfiltrates as point discharges through deep peat layers and as diffuse seepage through ditches cut into the sandy aquifer. The "pipe flow" channels were found in the deep peat area in the transition zones from deep peat to shallow peat. High-point discharges occur in vertical pipe-like channels, but discharge through the peat matrix itself is low. Dual porosity controls the groundwater exfiltration into the ditch. Groundwater exfiltrates locally in certain ditches. Consequently, the variation of baseflow is large between sub-catchments in these headwater peatland systems adjacent to esker aquifers.

In the artesian aquifer beneath the fen, the piezometric head showed a clear response to precipitation and evapotranspiration. Wetting of the peat is rapidly seen as a pressure increase in the confined aquifer. This provides new information on hydraulics of the wetlands found in aquifer discharge areas.

The results show that groundwater discharges from the esker aquifer in both deep and shallow peat layer areas. The low hydraulic conductivity of peat and a deep peat layer does not necessarily indicate poor connection between a fen and groundwater as assumed in previous studies. As high flow rate point discharges were found in ditch bottoms, peatland drainage can pose a risk to the esker aquifer: reduced flow resistance at the aquifer boundary can lower the groundwater level in the esker. This can have an immediate impact on lake water levels in the protected esker. Therefore more attention should be focused on impacts of peatland drainage on regional groundwater.

\section{Acknowledgments}

This study was funded by the EU 7th Framework programme GENESIS (Contract No. 226536), the Renlund Foundation and Maa- ja vesitekniikan tuki ry foundation.

\section{References}

Aapala, K. (Ed.), 2001. Assessment of the network of protected mires in Finland. The Finnish Environment 490 (abstract in English), 285 pp.

Allen, R.G., Pereira, S.L., Raes, D., Smith, M., 1998. Crop Evapotranspiration Guidelines for Computing Crop Water Requirements FAO Irrigation and Drainage Paper 56. FAO, Rome. 
Anibas, C., Buis, K., Verhoeven, R., Meire, P., Batelaan, O., 2011. A simple thermal mapping method for seasonal spatial patterns of groundwater-surface water interaction. J. Hydrol. 397 (1-2), 93-104

Beckwith, C.W., Baird, A.J., 2001. Effect of biogenic gas bubbles on water flow through poorly decomposed blanket peat. Water Resour. Res. 37 (3), 551-558.

Britschgi, R., Antikainen, M., Ekholm-Peltonen, M., Hyvärinen, V., Nylander, E., Siiro, P., Suomela, T., 2009. Pohjavesien kartoitus ja luokitus mapping and classification of groundwater areas. Environ Guide (Abstract in English), 75 pp.

Dahl, M., Nilsson, B., Langhoff, J.H., Refsgaard, J.C., 2007. Review of classification systems and new multi-scale typology of groundwater-surface water interaction. J. Hydrol. 344 (1-2), 1-16.

Davis, S.N., 1969. Porosity and permeability of natural materials. In: De Wiest, R.J.M. (Ed.), Flow Through Porous Media. Academic Press Inc., New York, pp. 53-89.

EC, 2008. Groundwater Protection in Europe. 35 pp.

Gilman, K., Newson, M., 1980. Soil pipes and pipeflow - a hydrological study in upland Wales. British Geol Res Group Res Monograph Ser 1 (London, UK).

Häikiö, J. 2008. The peatland and peat resources of Vaala Part 1. Report of peat investigation 383 (in Finnish). Geological Survey of Finland. 108 pp.

Holden, J., 2005. Piping and woody plants in peatlands: cause or effect? Water Resour. Res. 41, W06009.

Holden, J., Burt, T.P., 2002. Piping and pipeflow in a deep peat catchment. Catena 48 (3), 163-199.

Hooper, R., Shoemaker, C., 1986. A comparison of chemical and isotopic hydrograph separation. Water Resour. Res. 22 (10), 1444-1454.

Hvorselv, M.J. 1951. Time lag and soil permeability in ground-water observations. Waterways Experiment Station, Corps of Engineers, Bulletin no. 36, 50 pp.

Iorgulescu, I., Beven, K.J., Musy, A., 2005. Data-based modelling of runoff and chemical tracer concentrations in the Haute-Mentue research catchment (Switzerland). Hydrol. Process. 19 (13), 2557-2573.

Johansen, O.M., Pedersen, M.L., Jensen, J.B., 2011. Effect of groundwater abstraction on fen ecosystems. J. Hydrol. 402 (3-4), 357-366.

Kløve, B., Ala-aho, P., Okkonen, J., Rossi, P.M., 2011. Possible effects of climate change on hydrogeological systems: results from research on esker aquifers in
Northern Finland (Accepted), In Treidel, H., Bordes, J.L.M., Gurdak J. (Eds.), Climate Change Effects of Groundwater Resources: A Global Synthesis of Findings and Recommendations. UNESCO.

Langhoff, J.H., Rasmussen, K.R., Christensen, S., 2006. Quantification and regionalization of groundwater-surface water interaction along an alluvial stream. J. Hydrol. 320 (3-4), 342-358.

Lowry, C.S., Fratta, D., Anderson, M.P., 2009. Ground penetrating radar and spring formation in a groundwater dominated peat wetland. J. Hydrol. 373 (1-2), 6879 .

Mustonen, S., 1986. Sovellettu Hydrologia. Vesiyhdistys, Mänttä (in Finnish), 503 $\mathrm{pp}$

Ours, D.P., Siegel, D.I., Glaser, P.H., 1997. Chemical dilation and the dual porosity of humified bog peat. J. Hydrol. 196 (1-4), 348-360.

Päivänen, J. 1973. Hydraulic conductivity and water retention in peat soils. Acta Forestalia Fennica 129, 71 pp.

Pajunen, H. 1995. Holocene accumulation of peat in the area of an esker and dune complex, Rokuanvaara, Central Finland. Special paper 20, Geological Survey of Finland, pp. 125-133.

Price, J.S., 1992. Blanket bog in Newfoundland. Part 2. Hydrological processes. J. Hydrol. 135, 103-119.

Rintala, R. 2006. Maa-ainesten ottomäärät ja ottamislupatilanne 2004 -maaaineslain mukaiset ottoalueet, extractable land resource volumes and permits 2004 - extraction areas under the land extraction act. Finnish Environment 818 (Abstract in English), $71 \mathrm{pp}$.

Ronkanen, A.-K., Kløve, B., 2005. Hydraulic soil properties of peatlands treating municipal wastewater and peat harvesting runoff. Suo 56 (2), 43-56.

Schlotzhauer, S.M., Price, J.S., 1999. Soil water flow dynamics in a managed cutover peat field, quebec: field and labotary investigations. Water Resour. Res. 35 (12) 3675-3683.

SYKE (Finnish Environment Institute). 2011. Environmental Information System (HERTTA), Data downloaded 11 February 2011.

Wels, C., Cornett, R.J., Lazerte, B.D., 1991. Hydrograph separation: a comparison of geochemical and isotopic tracers. J. Hydrol. 122 (1-4), 253-274. 